\title{
PENGARUH PENAMBAHAN GARAM YANG BERBEDA TERHADAP TINGKAT KESEGARAN IKAN CAKALANG (Katsuwonus pelamis)
}

\author{
Effect of Different Additions of Salt on Freshness of Skipjack Fish (Katsuwonus pelamis) \\ Haslianti, Lia Mitra*, Suwarjoyowirayatno \\ Jurusan Teknologi Hasil Perikanan, Fakultas Perikanan dan Ilmu Kelautan Universitas Halu Oleo, Kendari, \\ Sulawesi Tenggara, Indonesia
}

*Email korespondensi: liamitra804@gmail.com (Telp: +6285256465841)

Diterima: 13 Januari/ Disetujui 16 Maret 2020

Cara sitasi: Haslianti, Mitra L, Suwarjoyowirayatno. 2020. Pengaruh penambahan garam yang berbeda terhadap tingkat kesegaran ikan cakalang (Katsuwonus pelamis). Jurnal Fish Protech. 3(1):95-103.

\section{ABSTRACT}

The aim of this study was to determine organoleptic changes, water content, $\mathrm{pH}$, TPC of skipjack tuna with different handling methods. This study used a Randomized Block Design (RBD) with 2 treatment factors, first treatment factor of adding salt consisting of 2 levels, 10\% salt (P0) and 15\% salt (P1). The second treatment factor is storage time which consists of 3 levels, $\mathrm{H} 1$ (1 days), $\mathrm{H} 2$ (2 days), and H3 (3 days). Organoleptic tests include gills, mucus, eyes, texture and aroma. while chemical tests include water content, $\mathrm{pH}$ and TPC. The results of the organoleptic test on the best treatment gill pameter $P 1 H 1$ with a value of 8,16 , mucus with a value of 8.16 , eyes with a value of 8,12 , aroma with a value of 8,04 and the best treatment texture at $\mathrm{POH} 1$ value of 8,04 . While the chemical test of water content was in the $\mathrm{P} 1 \mathrm{H} 1$ treatment with a value of $71,74 \%$, the lowest treatment in the $\mathrm{POH} 1$ with a value of $71,16 \%$. The highest value of $\mathrm{pH}$ parameters in the $\mathrm{P} 1 \mathrm{H} 1$ treatment with a value of $5,84 \%$, the lowest treatment at $\mathrm{POH} 1$ with a value of $5,64 \%$. The highest value of TPC parameters in the POH1 with a value of $4.67 \times 105 \mathrm{CFU} / \mathrm{g}$ and the lowest value in the P1H1 with a value of $4.29 \times 105$ CFU/g.

Keywords: addition of salt, freshness of fish, organoleptic test, skipjack fish, TPC.

\begin{abstract}
ABSTRAK
Tujuan penelitian ini adalah untuk mengetahui perubahan organoleptik, kadar air, pH, TPC ikan cakalang dengan metode penanganan yang berbeda. Penelitian ini menggunakan Rancangan Acak Kelompok (RAK) dengan 2 faktor perlakuan yaitu faktor perlakuan pertama penambahan garam yang terdiri dari 2 taraf yaitu penambahan garam 10\% $\left(P_{0}\right)$ dan penambahan garam $15 \%\left(P_{1}\right)$. Faktor perlakuan kedua adalah waktu penyimpanan yang terdiri dari 3 taraf yaitu $\mathrm{H}_{1}$ (1 hari), $\mathrm{H}_{2}\left(2\right.$ hari), dan $\mathrm{H}_{3}$ (3 hari). Uji organoleptik meliputi insang, lendir, mata, tekstur dan aroma. sedangkan uji kimia meliputi kadar air, pH dan TPC. Hasil penelitian uji organoleptik pada pameter insang perlakuan terbaik $\mathrm{P}_{1} \mathrm{H}_{1}$ dengan nilai sebesar 8,16, lendir dengan nilai sebesar 8,16, mata dengan nilai sebesar 8,12,aroma dengan nilai sebesar 8,04 dan tekstur dperlakuan terbaik pada $\mathrm{P}_{0} \mathrm{H}_{1}$ nilai sebesar 8,04 . Uji kimia nilai tertinggi uji kimia yaitu kadar air terdapat pada perlakuan $\mathrm{P}_{1} \mathrm{H}_{1}$ dengan nilai sebesar $71,74 \%$, perlakuan terendah pada perlakuan $\mathrm{P}_{0} \mathrm{H}_{1}$ dengan nilai sebesar $71,16 \%$. Parameter $\mathrm{pH}$ nilai tertinggi pada perlakuan $\mathrm{P}_{1} \mathrm{H}_{1}$ dengan nilai sebesar $5,84 \%$, perlakuan terendah pada $\mathrm{P}_{0} \mathrm{H}_{1}$ dengan nilai sebesar 5,64\%. Parameter TPC nilai tertinggi pada perlakuan $\mathrm{P}_{0} \mathrm{H}_{1}$ dengan nilai sebesar $4,67 \times 10^{5} \mathrm{CFU} / \mathrm{g}$ dan nilai terendah pada perlakuan $\mathrm{P}_{1} \mathrm{H}_{1}$ dengan nilai sebesar $4,29 \times 10^{5} \mathrm{CFU} / \mathrm{g}$.
\end{abstract}

Kata kunci: Ikan cakalang, kesegaran ikan, penambahan garam, TPC, uji organoleptik. 


\section{PENDAHULUAN}

Provinsi Sulawesi Tenggara merupakan salah satu Provinsi di Indonesia yang memiliki potensi perikanan yang cukup besar. Kendari sebagai ibu kota dari provinsi Sulawesi Tenggara berpotensi cukup besar dalam pengolahan perikanan, hal ini ditunjang dengan letak geografis kota Kendari yang berdekatan dengan Laut Banda yang dikenal memiliki ikan cakalang yang melimpah (Isamu, 2012).

Ikan cakalang merupakan hasil perikanan jenis pelagis. Ikan cakalang berukuran sedang dari familia Scombridae (tuna) adalah satu-satunya spesies dari genus Katsuwonus. Ikan berukuran terbesar, panjang tubuhnya bisa mencapai 1 meter dengan berat lebih dari $18 \mathrm{~kg}$. Cakalang yang banyak tertangkap berukuran panjang sekitar $50 \mathrm{~cm}$. Ikan cakalang dalam bahasa Inggris dikenal sebagai Skipjack tuna (Fausan, 2011).

Penanganan ikan cakalang yang kurang higienis serta penyimpanan dalam keadaan tidak dilindungi dengan baik mengakibatkan ikan sangat rentan terhadap kerusakan biologis. Kerusakan biologis dapat menyebabkan proses pembusukan pada ikan oleh bakteri berlangsung sangat cepat kebusukan pada ikan erat kaitannya dengan kerja bakteri pembusuk dan juga enzim baik yang dikeluarkan oleh bakteri maupun yang berasal dari tubuh ikan itu sendiri sehingga mempengaruhi kesegaran ikan (Heruwati, 2002).

Penurunan mutu pada ikan terjadi karena tingginya kerusakan pasca panen diakibatkan oleh antara lain cara penangkapan, cara penanganan yang buruk, panjangnya rantai suplai, tidak memadainya fasilitas penanganan. Cara penangkapan (jenis alat tangkap) secara langsung berhubungan dengan cara matinya ikan dan cara matinya ikan berhubungan dengan proses-proses fisik dan kimiawi yang dialami tubuh ikan dimana proses-proses tersebut berpengaruh langsung terhadap mutu ikan pasca tangkap. Hal ini dipengaruhi oleh cara penanganan ikan yang dilakukan tergolong masih buruk karena masih dilakukan seadanya tanpa memperhatikan syarat-syarat yang harus dipenuhi, baik menyangkut fasilitas penanganan maupun cara penanganan termasuk penggunaan es sebagai bahan pendingin ikan. Jika penanganan yang tidak baik pada ikan akan menimbulkan keracunan (Winarni et al., 2003).

Rahman et al., (2013) menjelaskan tentang pengaruh penambahan garam terhadap karakteristik organoleptik ikan lolosi merah (Caesio chrysozona) segar selama pemasaran rantai dingin. Hasil analisis menunjukan bahwa terjadi penurunan nilai organoleptik selama masa pemasaran. Nilai organoleptik tertinggi adalah 8 dengan spesifikasi yakni kenampakan mata cerah bola mata rata, kornea jernih, insang berwarna merah kurang cemerlang, tanpa lendir, lapisan lendir jernih, transparan, sayatan daging cemerlang spesifik jenis, dinding perut utuh, bau segar, spesifik jenis, dan tekstur elastis bila ditekan dengan jari, sulit menyobek daging dari tulang belakang. Menunjukkan penambahan garam memberikan pengaruh yang sangat nyata $(a<0,01)$ terhadap karakteristik mutu organoleptik ikan lolosi merah selama pemasaran rantai dingin. Dari berbagai penambahan konsentrasi garam yang diberikan penambahan garam 10\% $\quad$ (A3) menunjukan penurunan mutu yang paling lambat dan dapat mempertahankan mutu ikan tersebut sehingga masih layak dikonsumsi sampai dengan 48 jam masa pemasaran.

\section{METODE PENELITIAN}

\section{Alat dan Bahan}

Peralatan dalam penelitian ini yaitu styrofoam, timbangan analitik. Alat untuk uji kadar air yaitu oven, desikator dan cawan. Alat untuk uji pH yaitu pH meter, aquades. Alat yang digunakan untuk pengujian TPC penghitung koloni yaitu tabung erlenmeyer, gelas beker, magnetic stirrer, hot plate, autoclave, kertas label, timbangan analitik, stomacher, tabung reaksi dan rak, petridish, penghitung koloni, inkubator, oven dan mikro pipet.

Bahan yang digunakan dalam penelitian ini ikan cakalang (yang diperoleh dari TPI Kota Kendari, Sulawesi Tenggara), es batu, garam (garam mas). 
Bahan yang digunakan untuk uji kadar air yaitu sampel ikan cakalang. Bahan yang digunakan uji pH yaitu

\section{Rancangan Penelitian}

Rancangan penelitian yang digunakan adalah Rancangan Acak Kelompok (RAK) dengan dua taraf perlakuan yaitu PO (1 kg ikan : $2 \mathrm{~kg}$ es dengan penambahan garam 10\%), P1 (1 kg ikan: $2 \mathrm{~kg}$ es dengan penambahan garam 15\%) dan lama penyimpanan 1, 2, 3 hari dengan 3 kali ulangan, sehingga diperoleh 18 unit percobaan.

\section{Prosedur Penelitian}

\section{Persiapan bahan baku}

Bahan utama yang digunakan ikan cakalang yang diperoleh dari hasil tangkapan nelayan TPI Sohoda Kota Kendari. Dilakukan penimbangan awal ikan cakalang sebanyak $1 \mathrm{~kg}$, es batu $2 \mathrm{~kg}$ dan garam 10\% dan $15 \%$, kemudian dimasukkan dalam Styrofoam dengan ukuran panjang $39 \mathrm{~cm}$, lebar $25 \mathrm{~cm}$, tinggi 13 $\mathrm{cm}$ dan ketebalan $2 \mathrm{~cm}$. Selanjutnya penanganan awal yang berbeda pada ikan calakang dengan penambahan ikan dan es 1:2 dengan penambahan garam kasar $10 \%$ dan $15 \%$ dengan 3 kali ulangan aquades. Bahan yang digunakan untuk uji TPC meliputi nutrient agar dan aquades.

dengan penyusunan bagian bawah Styrofoam diberi es yang dtambahkan garam kemudian ikan disusun diatas es dan garam. Ikan cakalang yang sudah dilakukan penanganan disimpan selama 1, 2, 3 hari. Pengujian organoleptik, kadar air, pH, TPC..

\section{Variabel Pengamatan}

Parameter pengamatan pada penelitian ini terdiri dari parameter utama dan parameter pendukung. Parameter utama terdiri dari uji kadar air, $\mathrm{pH}$ dan TPC dan parameter pendukung terdiri dari uji organoleptik ikan cakalang segar yang disukai panelis meliputi kenampakan, aroma, dan tekstur.

\section{Analisis Data}

Data hasil penelitian organoleptik dianalisis mengunakan sidik ragam ANOVA ( Analysis of Variance). Jika terdapat perbedaan yang sangat nyata kemudian akan diuji lanjut mengunakan uji DMRT ( Duncan Multiple Range Test) dengan taraf kepercayaan $95 \%(\alpha=0,05)$.

\section{Hasil Penelitian}

\section{HASIL DAN PEMBAHASAN}

\section{Uji Organoleptik}

Nilai rerata uji organoleptik tiap perlakuan terhadap parameter, insang, lendir, mata, tekstur dan aroma dapat dilihat Tabel 1.

Tabel 1. Nilai rerata tertinggi kesegaran ikan cakalang dengan penambahan garam yang berbeda.

\begin{tabular}{llllll}
\hline Perlakuan & Insang \pm SD & Lendir \pm SD & Mata \pm SD & Tekstur \pm SD & Aroma \pm SD \\
\hline$P_{0}$ & $6,83 \pm 1,25$ & $6,94 \pm 0,98$ & $6,57 \pm \pm 1,26$ & $6,40^{a} \pm 1,27$ & $6,90 \pm 0,93$ \\
$P_{1}$ & $7,03 \pm 1,03$ & $6,88 \pm 0,88$ & $6,72^{b} \pm 1,09$ & $6,74^{b} \pm 0,93$ & $6,74 \pm 1,00$
\end{tabular}

Keterangan: Angka yang diikuti oleh notasi huruf yang sama menunjukan berbeda tidak nyata berdasarkan taraf kepercayaan $95 \%(\alpha=0,05)$.

Nilai rerata analisis ragam uji organoleptik pada kesegaran ikan cakalang terhadap waktu penyimpanan dapat kelihat pada Tabel 2. 
Tabel 2. Nilai rerata tertinggi kesegaran ikan cakalang terhadap lama penyimpanan.

\begin{tabular}{|c|c|c|c|c|c|}
\hline Perlakuan & Insang \pm SD & Lendir \pm SD & Mata \pm SD & Tekstur \pm SD & Aroma \pm SD \\
\hline $\mathrm{H}_{1}$ & $\begin{array}{l}8,01^{\circ} \pm \quad 0,11 \\
\text { (Insang } \\
\text { warna merah } \\
\text { kurang } \\
\text { cemerlang } \\
\text { tanpa lendir) }\end{array}$ & $\begin{array}{l}7,89 \mathrm{~b} \pm 0,13 \\
\text { (Lendir } \\
\text { mulai agak } \\
\text { keruh warna } \\
\text { agak putih) }\end{array}$ & $\begin{array}{l}7,69 \mathrm{c} \pm 0,25 \\
\text { (Cerah, bola } \\
\text { mata rata, } \\
\text { kornea jernih) }\end{array}$ & $\begin{array}{l}7,71^{\mathrm{c}} \pm \quad 0,15 \\
\text { (Agak padat, elastis bila } \\
\text { ditekan dengan jari sulit } \\
\text { menyobek daging dari } \\
\text { tulang) }\end{array}$ & $\begin{array}{l}7,55^{b} \pm 0,14 \\
\text { (Netral) }\end{array}$ \\
\hline $\mathrm{H}_{2}$ & $\begin{array}{l}7,04^{\mathrm{b}} \pm 0,11 \\
\text { (Warna merah } \\
\text { agak kusam } \\
\text { tanpa lendir) }\end{array}$ & $\begin{array}{l}6,82^{b} \pm 0,13 \\
\text { (Lendir agak } \\
\text { keruh, } \\
\text { warna putih } \\
\text { agak kusam) }\end{array}$ & $\begin{array}{l}6,88^{b} \pm 0,25 \\
\text { (Agak cerah, } \\
\text { bola mata } \\
\text { rata, pupil } \\
\text { keabu- } \\
\text { abuan) }\end{array}$ & $\begin{array}{l}6,47^{\mathrm{b}} \pm \\
\text { (Agak padat, bekas jari } \\
\text { sulit menyobek daging } \\
\text { dari tulang) }\end{array}$ & $\begin{array}{l}7,19 b \pm 0,14 \\
\text { (Netral) }\end{array}$ \\
\hline $\mathrm{H}_{3}$ & $\begin{array}{l}5,74^{a} \pm 0,11 \\
\text { (Mulai ada } \\
\text { perubahan } \\
\text { warna merah } \\
\text { kecoklatan) }\end{array}$ & $\begin{array}{l}6,03^{a} \pm 0,13 \\
\text { (Lendir agak } \\
\text { keruh, } \\
\text { warna putih } \\
\text { agak kusam) }\end{array}$ & $\begin{array}{l}5,37 \text { a } \pm 0,25 \\
\text { (Bola mata } \\
\text { agak cekung) }\end{array}$ & $\begin{array}{l}5,54 \text { a } \pm 0,15 \text { (Agak padat, } \\
\text { bekas jari sulit menyobek } \\
\text { daging dari tulang) }\end{array}$ & $\begin{array}{l}5,72^{\mathrm{a}} \pm 0,14 \\
\text { (Aroma } \\
\text { amoniak mulai } \\
\text { tercium sedikit } \\
\text { bau asam) }\end{array}$ \\
\hline
\end{tabular}

Keterangan: Angka yang diikuti oleh notasi huruf yang sama menunjukan berbeda tidak nyata berdasarkan taraf kepercayaan $95 \%(a=0,05)$.

\section{Analisis Kandungan Kimia}

Rekapitulasi perbandingan perlakuan terbaik dari semua parameter yang diuji berdasarkan uji indeks efektifitas. Nilai efektifitas yang diperoleh dikalikan dengan nilai normalisasi dari bobot yang diberikan untuk masing-masing parameter. Nilai jumlah terbesar merupakan perlakuan terbaik pada pengaruh penambahan garam yang berbeda terhadap tingkat kesegaran ikan cakalang disajikan pada Tabel 2.

Tabel 2. Rekapitulasi perbandingan perlakuan terbaik pada penanganan yang berbeda ikan cakalang

\begin{tabular}{llccc}
\hline No & Variabel & Penambahan garam & Perlakuan & \\
& pengamatan & $10 \%\left(\mathrm{P}_{0} \mathrm{H}_{1}\right)$ & $\begin{array}{c}\text { Penambahan garam } \\
15 \%\left(\mathrm{P}_{0} \mathrm{H}_{1}\right)\end{array}$ & Hasil penelitian lainnya \\
\hline 1. & Kadar air & 71,16 & 71,74 & $73,03 \% \%^{*}$ \\
2. & pH & 5,64 & 5,84 & $5,5^{* *}$ \\
3. & TPC & $4,67 \times 10^{*}$ & $4,29 \times 10^{\circ}$ & $5,0 \times 10^{* * *}$
\end{tabular}

Keterangan: $\mathrm{PoH}_{1}$ : Penambahan garam 10\% selama penyimpanan 1 hari

$\mathrm{P}_{1} \mathrm{H}_{1}$ : Penambahan garam $15 \%$ selama penyimpanan 1 hari

* : : Intarasiriswati, 2011

** : Metusalach el al., 2012

*** : SNI 2729: 2013 


\section{Pembahasan}

\section{Uji organoleptik}

\section{a. Insang}

Berdasarkan hasil perlakuan penanganan awal yang berbeda terhadap tingkat kesegaran ikan cakalang menunjukkan hasil perlakuan terbaik $\mathrm{P}_{1} \mathrm{H}_{1}$ (penambahan garam $15 \%$ dengan waktu penyimpanan 1 hari) dengan nilai sebesar 8,16. Hasil uji organoleptik menunjukkan warna merah kurang cemerlang tanpa lendir. Hal ini diduga karena dengan adanya penambahan konsentrasi garam maka akan menghambat proses penurunan pada tingkat kesegaran ikan. Penambahan garam 10\% dengan waktu penyimpanan 3 hari dengan nilai sebesar 5,24. Hasil uji organoleptik menunjukan mulai ada perubahan warna, merah kecoklatan, sedikit lendir. Perbedaan penurunan nilai organoleptik insang pada semua perlakuan diduga disebabkan perbedaan konsentrasi es dan garam yang digunakan sehingga memberikan pengaruh yang tidak nyata terhadap keadaan insang ikan cakalang. Menurunnya nilai organoleptik pada semua konsentrasi penambahan dan lama penyimpanan disebabkan oleh peningkatan suhu ikan cakalang sehingga nilai organoleptik terus menurun. Menurut Junianto (2003), proses perubahan pada ikan setelah mati terjadi karena adanya aktivitas enzim, mikroorganisme, dan kimiawi. Ketiga hal tersebut menyebabkan tingkat kesegaran ikan menurun. Penurunan tingkat kesegaran ikan tersebut dapat dilihat dengan adanya perubahan fisik, kimia, dan organoleptik pada ikan.

Penelitian sebelumnya analisis organoleptik ikan cakalang segar yang diawetkan dengan es air kelapa fermentasi nilai organoleptik insang ikan cakalang menurun seiring dengan lamanya penyimpanan. Nilai organoleptik insang tertinggi yaitu pada perlakuan dengan penyimpanan 0 hari pada semua taraf fermentasi air kelapa yaitu 8,72 dan nilai terendah adalah dari perlakuan penggunaan es air tawar (kontrol) selama penyimpanan 12 hari yaitu 4,16 (Suara et al., 2014).

\section{a. Lendir}

Berdasarkan hasil rerata penanganan awal yang berbeda terhadap tingkat kesegaran ikan cakalang menunjukkan hasil perlakuan terbaik pada $\mathrm{P}_{1} \mathrm{H}_{1}$ (penambahan garam 15\% dengan waktu penyimpanan 1 hari) dengan nilai sebesar 8,16. Hasil uji organoleptik lendir menunjukan lapisan lendir jernih, transparan, cerah belum ada perubahan. Penambahan garam pada perlakuan terendah $\mathrm{P}_{0} \mathrm{H}_{3}$ (penambahan garam $10 \%$ dengan waktu penyimpanan 3 hari) dengan nilai 5,76 . Hasil uji organoleptik menunjukan lendir tebal mengumpal, mulai berubah warna putih, keruh. Hal ini diduga karena suhu yang meningkat dalam styrofoam berinsulasi menyebabkan proses kemunduran mutu dari ikan cakalang lebih cepat. Secara organoleptik kemunduran mutu dapat dilihat dari lapisan lendir tebal menggumpal, kenampakan daging mulai berubah menjadi berwarna putih, keruh dan bau amoniak mulai tercium. Pelepasan lendir dari kelenjar lendir ini merupakan reaksi alami ikan yang sedang sekarat terhadap keadaan yang tidak menyenangkan. Jumlah lendir yang terlepas dan menyelimuti tubuh dapat sangat banyak hingga mencapai $1-2,5 \%$ dari berat tubuhnya (Afrianto dan Liviawaty, 2010).

Suhu yang meningkat dalam Styrofoam berinsulasi menyebabkan proses kemunduran mutu dari ikan lebih cepat. Penurunan nilai mutu organoleptik ikan cakalang pada penyimpanan hari ke 3 ditandai adanya lapisan lendir pada permukaan tubuh ikan cakalang tebal menggumpal, berwarna putih kuning, dan bau amoniak kuat, sehingga tidak layak dikonsumsi karena belum memenuhi syarat mutu organoleptik ikan segar sesuai dengan SNI 012729.1-2006.

\section{b. Mata}

Berdasarkan hasil rerata penanganan awal yang berbeda terhadap tingkat kesegaran ikan cakalang menunjukkan hasil perlakuan terbaik pada terbaik $\mathrm{P}_{0} \mathrm{H}_{1}$ (penambahan garam $10 \%$ dengan waktu penyimpanan 1 hari) dengan nilai 8,12. Hasil uji menunjukan mata ikan masih segar dengan kategori cerah, bola mata menonjol dan kornea jernih. Hal ini diduga karena penambahan garam dan es sehingga sistem rantai dingin pada ikan dapat berlangsung dengan baik dan menjaga kesegaran ikan agar tetap segar selama penyimpanan dalam box Styrofoam. 
Perbandingan bahan baku dan media es 1:2 mampu menjaga suhu pusat ikan lebih lama sehingga kesegaran tetap terjaga ( Junianto, 2003).

Hasil uji perlakuan terendah $\mathrm{P}_{0} \mathrm{H}_{3}$ (penambahan garam 10\% dengan waktu penyimpanan 3 hari) dengan nilai sebesar 5,16 . Hasil uji organoleptik menunjukan perubahan pada mata yang diakibatkan oleh bakteri dipicu terjadi perubahan pada mata yaitu bola mata agak cekung, pupil keabu-abuan, kornea agak keruh keabuan, dan kornea agak keruh. Hal ini dikarenakan perlakuan mengunakan garam dan es selama penyimpanan 3 hari menyebabkan aktivitas bakteri dan mikroba sangat aktif dan merusak jaringan ikan. Semakin lama waktu penyimpanan maka nilai organoleptik mata semakin menurun. Menurut Sanger (2010), pola dan laju penurunan mutu ikan sangat dipengaruhi oleh keadaan temperatur, dimana semakin tinggi suhu semakin cepat pula penurunan mutu kesegaran.

Standar mutu ikan segar (SNI 01-2346-2006) menunjukkan bahwa mata ikan dengan perbandingan ikan dan es 1: 2 dengan penambahan garam 15\% selama penyimpanan 1 hari dengan nilai sebesar 8,12 masih memenuhi syarat nilai organoleptik yakni minimal 7 sedangkan perbandingan $1: 2$ dengan penambahan $10 \%$ selama penyimpanan 3 hari belum memenuhi syarat yakni bola mata keabu-abuan, kornea agak keruh.

\section{c. Aroma}

Berdasarkan hasil rerata penanganan awal yang berbeda terhadap tingkat kesegaran ikan cakalang menunjukkan hasil perlakuan terbaik pada terbaik $\mathrm{P}_{1} \mathrm{H}_{1}$ (penambahan garam $10 \%$ dengan waktu penyimpanan 1 hari) dengan nilai 8,04 . Hasil organoleptik menunjukan segar, spesifik jenis ikan mutu yang baik pada aroma disebabkan oleh pemberian garam pada media es sehingga sistem rantai dingin pada ikan dapat berlangsung dengan baik dan menjaga bau ikan tetap menghasilkan aroma segar selama proses penyimpanan pada box styrofoam karena terhentinya metabolisme pada ikan yaitu melambatknya perombakan yang terjadi pada protein menjadi asam laktat sebagai penyebab terjadinya bau busuk (Aprianti, 2011).
Hasil uji organoleptik perlakuan terendah $\mathrm{P}_{0} \mathrm{H}_{3}$ (penambahan garam 10\% dengan waktu penyimpanan 3 hari) dengan nilai 5,52 . Hasil uji organoleptik yang dilakukan menunjukan adanya penurunan mutu pada hari pertama masih tercium aroma segar namun pada hari kedua dan ketiga sudah tercium aroma tengik seiring dengan lama penyimpanan. Hal ini dikarenakan adanya reaksi senyawa glikogen yang terjadi pada ikan setelah mengalami rigor mortis. Hal ini sesuai pendapat Syamsir (2008), bahwa faktor yang menyebabkan ikan cepat mengalami bau busuk adalah kadar glikogennya rendah sehingga rigor mortis berlangsung lebih cepat. Glikogen dan glukosa pada hewan yang mati dapat mengalami glikolisis menjadi asam piruvat yang selanjutnya diubah menjadi asam laktat.

Hasil uji organoleptik menunjukan bahwa tidak terdapat pengaruh yang nyata pada interaksi sedangkan penambahan garam berpengaruh nyata dan lama penyimpanan pada ikan cakalang berpengaruh sangat nyata. Pertumbuhan mikroorganisme pada tubuh ikan yang sudah mati sangat dipengaruhi oleh suhu pusat ikan sehingga semakin tinggi suhu pusat ikan makan proses metabolisme pada ikan akan semakin cepat yang mengakibatkan pertumbuhan mikroorganisme semakin meningkat (Siswanto, 2008).

\section{d. Tekstur}

Berdasarkan hasil rerata penanganan awal yang berbeda terhadap tingkat kesegaran ikan cakalang menunjukkan hasil perlakuan terbaik pada terbaik $\mathrm{P}_{0} \mathrm{H}_{1}$ (penambahan garam $10 \%$ dengan waktu penyimpanan 1 hari) dengan nilai 8,04 . Hasil uji organoleptik pada mutu yang baik pada tekstur disebabkan oleh penggunaan media es yang ditambahkan garam sehingga sistem rantai dingin pada ikan dapat berlangsung dengan baik dan menjaga tekstur ikan tetap menghasilkan mutu daging yang masih segar selama proses penyimpanan pada box sterofoam sehingga mampu memperpanjang fase rigor pada ikan (Enampato, 2011).

Hasil uji organoleptik perlakuan terendah $\mathrm{P}_{0} \mathrm{H}_{3}$ (penambahan garam $15 \%$ dengan waktu penyimpanan 3 hari) dengan nilai 5,52 mengalami 
penurunan mutu hal ini disebabkan adanya aktivitas mikroorganisme yang berpengaruh keadaan tekstur terjadi pelunakan, bekas jari terlihat bila ditekan, mudah menyobek daging dari tulang belakang. Hal ini diperkuat oleh Berhimpon (1993) yaitu perubahan tekstur daging menjadi lebih lunak terjadi apabila ikan sudah mulai mengalami kemunduran mutu. Daging pada ikan yang mengalami kemunduran mutu apabila ditekan tekstur dagingnya lunak atau tidak elastis lagi. Daging mulai berubah menjadi lunak apabila ditekan dengan jari karena adanya perombakan pada jaringan otot daging oleh proses enzimatis.

Standar mutu ikan segar (SNI 01-2346-2006) menunjukkan bahwa tekstur ikan dengan perbandingan ikan dan es 1:2 dengan penambahan garam $10 \%$ selama penyimpanan 1 hari dengan nilai sebesar 8,04 memenuhi syarat nilai organoleptik yakni minimal 7 sedangkan perbandingan ikan dan es 1:2 dengan penambahan garam $15 \%$ selama penyimpanan 3 hari dengan nilai sebesar 5,52 belum memenuhi syarat.

\section{Uji kimia}

\section{a. Nilai Kadar air}

Berdasarkan hasil terbaik dengan metode indeks efektifitas kadar air ikan cakalang segar bahwa nilai tertinggi $71,74 \%$ ( dengan penambahan garam 15 $\%$ selama penyimpanan 1 hari) sedangakan nilai terendah $71,16 \%$ (dengan penambahan garam 10\% selama penyimpanan 1 hari). Perbedaan kadar air ikan cakalang segar disebabkan oleh teknik penanganan ikan yang berbeda. Sebagian air yang dikandung oleh ikan cakalang digunakan oleh bakteri untuk proses metabolisme dan sebagian lagi hilang akibat proses penguapan air bebas. Hal ini diduga penguapan air yg terjadi pada teknik penambahan yang berbeda dan penambahan garam yang $15 \%$ lebih tinggi akibat suhu lingkungan yang lebih tinggi dibandingkan suhu ikan sehingga kadar air sampel menjadi sebesar $71,74 \%$. Penambahan garam 10\% kadar air 71,16 menyebabkan air bebas tertarik keluar sehingga terjadi perbedaan kadar air yang disebabkan oleh jumlah dan aktivitas bakteri yang sangat membutuhkan air bebas untuk pertumbuhannya.
Penurunan kadar air disebabkan faktor lingkungan seperti suhu penyimpanan dan adanya penambahan garam. Pertumbuhan dan kelangsungan hidup bakteri sangat tergantung pada air bebas yang mutlak diperlukan untuk kelangsungan metabolisme bakteri. Kadar air merupakan komponen penting pada bahan pangan karena air dapat mempengaruhi kenampakan, tekstur sehingga kadar air ikut menentukan kesegaran bahan pangan, namun jika suhu ditingkatkan melebihi keseimbangan $\mathrm{RH}$ di udara maka molekul air akan bergerak menuju ke permukaan dan akhirnya menguap. Kandungan air yang dinyatakan dengan air bebas dapat dimanfaatkan oleh bakteri untuk pertumbuhannya (Pandit, 2004).

\section{b. Nilai pH}

Berdasarkan hasil dari pemilihan perlakuan terbaik dengan metode indeks efektifitas nilai pH pada penanganan yang berbeda pada tingkat kesegaran ikan cakalang dengan penambahan garam penyimpanan 1 hari adalah $\mathrm{P}_{1} \mathrm{H}_{1}$ (penambahan garam $15 \%$ selama penyimpanan 1 hari ) 5,84\% dengan nilai tertinggi $\mathrm{pH}$ dan $\mathrm{P}_{0} \mathrm{H}_{1}$ (penambahan garam 10\% selama penyimpanan 1 hari) $5,64 \%$ dengan nilai terendah. Penambahan garam 10\% selama penyimpanan 1 hari mengalami penurunan $\mathrm{pH}$. Hal ini sesuai dengan pendapat Naim 1990, bahwa ikan setelah mati, sirkulasi darah terhenti sehingga mengakibatkan perubahan yang terjadi dalam jaringan otot. Terhentinya suplai $\mathrm{O}_{2}$ sehingga mempengaruhi metabolisme dalam tubuh. Pernapasan terhenti mengakibatkan terjadinya glikolisis yang merubah glikogen menjadi asam laktat yang menurunkan $\mathrm{pH}$ tubuh ikan. Wangsadinata (2008) menyatakan bahwa $\mathrm{pH}$ ikan saat proses produksi dan saat dipelelangan mengalami penurunan karena adanya glikogen menjadi asam laktat. Semakin lama waktu penyimpanan semakin besar pula penurunan $\mathrm{pH}$. Jika cadangan glikogen telah habis terurai maka $\mathrm{pH}$ daging akan mengalami penurunan. Selama proses kemunduran mutu akan meningkatkan $\mathrm{pH}$ daging ikan dan semakin tinggi tingkat pembusukan maka semakin tinggi pula pembusukan. 


\section{c. TPC}

Berdasarkan hasil dari pemilihan perlakuan terbaik dengan metode indeks efektifitas nilai TPC ikan cakalang segar bahwa nilai tertinggi TPC ikan cakalang segar adalah 4,67 × $10^{5}$ (dengan penambahan garam $10 \%$ selama penyimpanan 1 hari) dan nilai terendah $4,29 \times 10^{5}$ (dengan penambahan garam 15\% selama penyimpanan 1 hari). Nilai TPC ikan cakalang masih memenuhi standar SNI 2013 dimana batas maksimum cemaran ALT 5,0 $\times 10^{5}$. Penurunan dengan pengunaan suhu dan penambahan garam dengan konsentrasi yang berbeda hal ini disebabkan garam dapat menghambat pertumbuhan mikroorganisme. Menurunnya total mikroba disebabkan perubahan dan komposisi mikroorganisme dipengaruhi oleh suhu, jika suhu meningkat, maka kecepatan metabolisme naik dan pertumbuhan mikroorganisme akan cepat, sebaliknya bila suhu mengalami penurunan maka kecepatan metabolisme juga akan menurun dan pertumbuhan mikroorganisme akan lambat (Adawyah, 2007).

Penyimpanan 1 hari masih mampu menghambat pertumbuhan bakteri, sedangkan pada penyimpanan 2 dan 3 hari tidak mampu menghambat pertumbuhan bakteri. Penyebabnya, semakin lama waktu penyimpanan maka semakin cepat es mencair. Es yang cepat mencair disebabkan suhu panas dari tubuh ikan maupun dari luar cool box berinsulasi yang diikuti dengan peningkatan suhu dalam cool box. Peningkatan suhu dalam cool box berinsulasi selama

\section{DAFTAR PUSTAKA}

Adawyah, R. 2007. Pengolahan dan Pengawetan Ikan. Bumi Aksara. Jakarta.

Afrianto, E dan Liviawaty, E. 2010. Proses Penurunan dan Cara Mempertahankan Kesegaran Ikan. Widya Padjadjaran. Bandung.

Aprianti, D. 2011. Aktivitas Antibakteri Ekstrak Biji Picung (Pangium edule Reinw) dan Pengaruhnya terhadap Stabilitas Fisika Kimia, Mikrobiologi dan Sensori Ikan Kembung (Rastrelliger neglectus). [Skripsi]. Program Studi Kimia. Fakultas Sains dawinarnon Teknologi. Universitas Islam penyimpanan 2 dan 3 hari menyebabkan peningkatan jumlah bakteri. Peningkatan suhu dalam cool box memengaruhi peningkatan jumlah nutrisi, perubahan $\mathrm{pH}$ pada tubuh ikan cakalang yang diperlukan untuk pertumbuhan bakteri, sehingga bakteri cepat mengalami peningkatan (Afrianto dan Liviawaty, 2010).

\section{KESIMPULAN}

Berdasarkan hasil analisa statistik dan pembahasan dapat ditarik kesimpulan sebagai berikut:

1. Terdapat pengaruh pada penanganan awal berbeda terhadap tingkat kesegaran ikan cakalang pada lama penyimpanan 1, 2 dan 3 hari berpengaruh nyata terhadap insang, lendir, mata, tekstur dan aroma. Penambahan garam yang berbeda berpengaruh nyata terhadap uji organoleptik mata dan tekstur namun berpengaruh tidak nyata pada insang, lendir dan aroma, sedangkan pada interaksi berpengaruh nyata terhadap tekstur namun berpengaruh tidak nyata pada insang, lendir, mata, dan aroma.

2. Terdapat pengaruh pada penanganan awal berbeda terhadap tingkat kesegaran ikan cakalang perlakuan dari hasil analisis menunjukan penambahan garam berpengaruh sangat nyata terhadap lama penyimpanan setiap perlakuan $\mathrm{P}_{0} \mathrm{H}_{1}$ dan $\mathrm{P}_{1} \mathrm{H}_{1}$ dengan nilai $\mathrm{pH}$ tertinggi $\mathrm{P}_{1} \mathrm{H}_{1}$, Kadar air tertinggi pada $\mathrm{P}_{1} \mathrm{H}_{1}$, dan TPC tertinggi pada $\mathrm{P}_{0} \mathrm{H}_{1}$ dan terendah $\mathrm{P}_{1} \mathrm{H}_{1}$.

Negeri Syarif Hidayatullah. Jakarta. Hal. 3840.

Berhimpon S. 1993. Mikrobiologi Perikanan Ikan Bagian 1 Ekologi dan Pertumbuhan Mikroba serta Pertumbuhan Biokimia Pangan. Laboratorium Pengolahan dan Pembinaan Mutu Hasil Perikanan. Fakultas Perikanan dan IImu Kelautan. Universitas Sam Ratulangi. Manado.

Enampato, M.H. 2011. Inventarisasi Keragaman Mutu Produk Ikan Tandipang (Dussumieria acuta C.V.) Asap Kering Produksi Rusmah Tangga Didesa Matani I Kecamatan 
Tumpaan. [Skripsi]. Fakultas Perikanan dan IImu Kelautan. UNSRAT. Manado.

Fausan. 2011. Pemetaan Daerah Potensial Penangkapan Ikan Cakalang (Katsuwonus pelamis) Berbasis Sistem Informasi Geografis Diperairan Teluk Tomini Provinsi Gorontalo. [Skripsi]. Fakultas Perikanan dan Kelautan Universitas Hasanuddin Makassar.

Heruwati. 2002. Pengolahan Ikan Secara Tradisional Prospek dan Peluang Pengembangan. Jurnal Litbang Pertanian.

Isamu, K.T., H. Purnomo dan S.S. Yuwono. 2012. Karateristik Fisik, Kimia dan Organoleptik Ikan Cakalang (Katsuwonus pelamis) Asap di Kendari. Jurnal Teknologi. 13 ( 2 ) : 105-110. Intarasiriswati, C., Benjakul S dan Visessanguan, W. 2011. Chemical Compusitions of The Roes From Skipjack, Tongkol, and Banito. Journal Foof Chemistry 124 (11): 13-28.

Junianto. 2003. Teknik Penanganan Ikan. Penebar Swadaya. Jakarta.

Metusalaac. Kasmiati dan Fahrul. 2012. Analisis Hubungan antara Cara Penangkapan dan Cara Penanganan dengan kualitas Ikan yang Dihasilkan (Laporan Hasil Penelitian) LP2M. UNHAS.

Nam, E. 1990. Biochemestry of foods, Canada : academic press inc.

Pandit, I.G.S., 2004. Teknologi Penanganan dan Pengolahan Ikan. Penerbit PT. Bali Post. Denpasar.

Rahman, D. S. Nalu. A.S dan Mile Lukman. 2013. Pengaruh Penambahan Garam terhadap Karateristik Organoleptik Ikan Lolosi Merah (Caesio chrysozona) Segar selama Pemasaran Rantai Dingin. Jurusan Teknologi Perikanan. Fakultas IImu Pertanian. Universitas Gorontalo.

Sanger, G. 2010. Mutu kesegaran ikan tongkol (Auxis tazard) selama penyimpanan dingin. Warta IPTEK. Jakarta. $43 \mathrm{hlm}$.

Siswanto H., dan Soedarto. 2008. Respon Kualitas Bandeng (Chanos Chanos) Asap terhadap Lama Pengeringan. Berkala IImiah Perikanan 3.

BSN [Badan Standarisasi Nasional]. 2013. Ikan Segar. SNI 2729:2013. Jakarta.

2006. Penentuan Angka Lempeng Total (ALT) pada Produk Perikanan. SNI 01.2332.3-2006. Jakarta.
Suara, Y. Asri Silvana Naiu. Mile, L. 2014. Analisis Organoleptik pada Ikan Cakalang Segar yang Diawetkan dengan Es Air Kelapa Fermentasi. Jurnal IImiah Perikanan dan Kelautan. Vol. 2 (3). Universitas Negeri Gorontalo.

Syamsir, E. 2008. Proses Pembusukan Ikan. http: // id. Shvoong. Com/exact- sciences / 1790308proses-pembusukan-ikan. [23 Maret 2017].

Wangsadinata, V. 2008. Sistem Pengendalian Mutu Ikan Swanggi (Pricanthus macracanthus) Studi Kasus di CV Bahari Express, Pelabuhan Ratu, Sukabumi. [Skripsi]. IPB. Bogor.

Winarni, T., Swastawati, F., Darmanto, Y.s., dan Dewi, E.N. 2003. Uji Mutu Terpadu pada Beberapa Spesis Ikan dan Produk Perikanan Di Indonesia. Laporan Akhir Hibah Bersaing. XI Perguruan Tinggi. Universitas Diponegoro. Semarang. 